Frontmatter

\title{
REFLECTIONS ON THE STRUGGLE AGAINST THE CANADA-US FREE TRADE AGREEMENT (FTA), 30 YEARS LATER
}

\author{
CHRIS HURL AND BENJAMIN CHRISTENSEN
}

\begin{abstract}
The implementation of the Canada-US Free Trade Agreement (CUSFTA) in January 1989 marked a decisive moment in the rise of neoliberalism as a political project in Canada. While the left, and socialist political economists in particular, played a central role in galvanizing opposition to the agreement and contributed in no small part to the demise of the Conservative government in 1993, the free trade agenda continued to move forward through the 1990s. This Special Issue revisits the history of struggles against free trade in Canada with two aims in mind: first to remember the coalitions through which opposition was organized, the mobilization of socialist critiques by activists and intellectuals, and the key events leading up to the adoption of the agreement. Second, drawing from this history to make sense of how things have changed over the past 30 years, as right-wing nationalists have increasingly taken the lead in opposing free trade, while neoliberals have sought to rebrand their project as 'progressive'. How can those on the left effectively confront the project of free trade today while at the same time challenging both far-right nationalism and neoliberal globalization?
\end{abstract}

\section{In Memory of Mel Watkins (1932-2020)}

This Special Issue is dedicated to the memory of Mel Watkins. A prolific activist and scholar, Watkins played a central role in organizing opposition to free trade, which he described as a "charter of rights for corporations," in the 1980s and early 1990s. As a scholar, Watkins championed staples theory, providing the left with a powerful economic vocabulary for critiquing free trade. As an activist, Watkins served as a key advisor and spokesperson for the coalitions arising through the period, where he galvanized popular opposition to these agreements. We encourage readers to view the tributes to Watkins on the journal's website, including from contributors Marjorie Griffin Cohen and Paul Kellogg.

\section{Introduction}

"Canadian workers and their families are currently being subjected to the Canadian version of a worldwide phenomenon - a 'back-to-the-market' philosophy pushed 
by right-wing governments and their friends in the business community. The aim is to return to a system where the market reigns supreme, where the weak are at the mercy of the strong. The push by neo-conservative elements in our country toward a market dominated economy threatens the very fabric of our society, reducing it to a jungle where the strong survive and the weak are left by the wayside" (Canadian Labour Congress, 1986).

"Our politicians have aggressively pursued a policy of globalization, moving our jobs, our wealth and our factories to Mexico and overseas. Globalization has made the financial elite, who donate to politicians, very, very wealthy. I used to be one of them... I hate to say it, but I used to be one. But it has left millions of our workers with nothing but poverty and heartache. When subsidized foreign steel is dumped into our markets, threatening our factories, the politicians have proven, folks, have proven they do nothing" (Donald Trump, 2016).

What a difference 30 years makes: These days, free trade has been taken up as a central target by right populist politicians. From Donald Trump to Boris Johnston, it is argued that free trade policies have been bad for working people. In his campaigning, Trump repeatedly pointed out that these "foolish" policies have led to the exodus of good jobs from the United States. More recently, Canadian Conservative leader, Erin O'Toole has echoed this approach, blaming "corporate and financial power brokers who care more about their shareholders than their employees. They love trade deals with China that allow them to access cheap labour" (as reported in The National Post, September, 9, 2020). Parroting Trump, he has advocated a "Canada First" strategy with the aim of winning over working-class voters.

It was not always this way. From the mid-1980s to the early 2000s, opposition to free trade served as a focal point for the left across Canada. In confronting a wave of trade agreements - such as CUSFTA (1988), NAFTA (1994), the MAI (1995) and the FTAA (2001) ${ }^{1}$ - as well as nascent transnational organizations such as the World Trade Organization (WTO), a wide array of different groups came together - from labour unions, environmental activists, and women's groups to progressive religious organizations, Indigenous communities and artist collectives. Through such organizing, free trade became the key reference point for the 1988 federal election, which became known as the "Free Trade" election. Moreover, it provided an enduring basis for left organizing, leading to the establishment of longstanding relationships and distinctive repertoires for organizing, which oriented opposition to neoliberal economic policies over the next thirty years. How did things change?

This Special Issue considers the legacy of the struggle against free trade in Canada, with a focus on the early years. It is inspired by a roundtable session organized at the 2019 conference of

\footnotetext{
${ }^{1}$ Canada-US Free Trade Agreement (CUSFTA); North American Free Trade Agreement (NAFTA); Multilateral Agreement on Investment (MAI); Free Trade Area of the Americas (FTAA)
} 
the Society for Socialist Studies reflecting on the thirty-year anniversary of the Canada-US Free Trade Agreement (CUSFTA). Its implementation on 1 January 1989 significantly reduced tariffs and deregulated investment between the two countries, marking a decisive shift towards the establishment of a cross-national neoliberal economic regime.

Building from our discussion, this Special Issue revisits the history of struggles against free trade in Canada with two aims in mind: first to remember the coalitions through which opposition was organized, the mobilization of socialist critiques by activists and intellectuals, and the key events leading up to the adoption of the agreement. Second, drawing from this history to make sense of how things have changed over the past 30 years, as right-wing nationalists have increasingly come to prominence as opponents of free trade, while neoliberals have sought to rebrand their project as 'progressive'. How can those on the left effectively confront the project of free trade today while at the same time challenging both far-right nationalism and neoliberal globalization?

In this introduction, we set the stage, speaking to our motivations in putting this volume together. We begin by addressing the significance of free trade in shaping the politics of the period, while also discussing the importance of remembering the collective work of activists during this time. We then introduce key questions that we have posed to our contributors - Marjorie Griffin Cohen, William Carroll, Paul Kellogg, and Claude Vallancourt. We conclude by identifying areas for future discussion and research.

\section{The Importance of Remembering}

While Conservative leader Erin O’Toole has taken aim at free trade as a means of winning over working class voters, it should be remembered that it was the Progressive Conservative Party led by Prime Minister Brian Mulroney, who, on 26 September 1985, officially opened the door to free trade talks with the United States. Drawing from the recommendations of the Macdonald Commission Report, released that year, Mulroney proposed to President Ronald Reagan in a formal letter "the broadest possible package of mutually beneficial reductions in barriers to trade in goods and services." ${ }^{2}$ Over the course of the following three years, both governments moved towards an agreement, contributing to the entrenchment of a neoliberal regime of deregulation, outsourcing, and privatization that would be consolidated over the next three decades.

In response to Mulroney's efforts, powerful coalitions emerged across Canada that drew together an array of actors in opposition. Organizations like the Council of Canadians (1985), the Coalition Against Free Trade (1985), and Pro-Canada Network (1987) came onto the scene, generating research and analysis on issues related to free trade, while organizing conferences, rallies, fundraisers, and other events, cultivating alliances between a wide array of different groups. Through these networks, a powerful left formation was forged, fostering a shared language that

\footnotetext{
2 https://www.reaganlibrary.gov/archives/speech/statement-principal-deputy-press-secretary-speakes-canadaunited-states-free-trade
} 
enabled those on the left in Canada to imagine themselves as part of a common movement while reshaping the political landscape of the period (McKay, 2005).

However, while free trade became a key reference point orienting left wing activism from the mid-1980s to the early 2000s, there is very little research documenting its history. There are only a handful of books and articles looking at the movement against it (for Canada, see Ayres, 1998; Bashevkin, 1989; Hamelin, 2017; Huyer, 2004; Kellogg, 2019). Most of this history is focused on the struggles of the 1990s, from the 1994 Zapatista rebellion through to the 1999 WTO protests. Recently, there have been a number of initiatives to build public archives that remember these struggles. For instance, the WTO History project at the University of Washington has generated an extensive archive and database documenting the organizing leading up to the 1999 protests in Seattle. ${ }^{3}$ However, there is very little research that documents the early coalitions, especially in Canada.

This special issue is an invitation to foster this collective memory, recognizing how the coalitions and movements against free trade during this period have made powerful contributions in shaping the present. Remembering all of the work, relationships and discussions that went into building opposition to free trade is vital in challenging what Kinsman (2018:313) describes as the social organization of forgetting, through which "we are denied access to the social and historical literacies that would allow us to feel and hear the struggles of people that won us ... the gains that are currently being cut and curtailed." Several generations of activists and scholars carved their teeth through the struggle against free trade, developing intergenerational communities of learning and support, repertoires for organizing and coalition-building, journals and publishing companies that endure to this day. Looking back to the early struggles against free trade help us to understand where these capacities came from.

Moreover, it speaks to the potential power of left formations in shaping public discourse. Over the course of the three years leading up to the adoption of free trade, activists on the left working in coalitions were able to make the 1988 election a public referendum on free trade. While free trade activists failed to stop the agreement - with the federal Conservatives winning $50.3 \%$ of the popular vote and claiming 169 out of 295 seats - they were successful in making free trade a public issue, and a central area of popular discussion and debate over the course of the next decade. From the 1988 elections to the 2001 FTAA protests in Quebec City, the free trade question was persistently posed as a central area of debate that framed political alignments between the left and the right. Through fostering critical literacies on free trade and its potential impacts on working people, activists were able to make this a public issue.

Revisiting this history also puts in context the current discussions around free trade. Each of the contributions to the special issue speak to the tensions and contradictions of the left formation at the time that, helping us to understand how opposition to free trade can also pivot to the right. A central and enduring question arising from these struggles has been the left's relationship to nationalism. In the early years, nationalism provided a central reference point for

\footnotetext{
${ }^{3}$ https://depts.washington.edu/wtohist/
} 
opponents of free trade. "Under a free trade arrangement," Duncan Cameron (1985, xxv) argued in The Other Macdonald Report, "Canada gives up the world for the right to be inside the American protectionist wall...free trade is only a code word for continental integration, the preferred solution of most of Canada's economic elite." Left nationalists viewed free trade as jeopardizing Canadian jobs while imperiling cultural identity, and instead advocated an economically independent Canada. However, the focus on national identity, risked marginalizing other voices such as indigenous people and those in Québec, for whom the national project was steeped in colonialism - and foreclosing on potential alliances that could be forged with workers in other countries. By revisiting these debates, we aim to help contextualize these understandings of nationalism in a way that informs left strategies going forward.

\section{The Contribution of the Special Issue}

Building from the 2019 roundtable session, we invited four activists and scholars to contribute to this Special Issue. Each participated in the struggle against free trade in different capacities - coming from different regions across Canada - and brings a unique perspective in discussing its legacy.

In guiding the conversation, we posed the following questions to them:

- How did you become involved in the struggles around free trade in the 1980s?

- To what extent were these struggles successful? What setbacks did you experience?

- What is the legacy of the struggle against free trade today? What lessons can be learned?

- To what extent is the struggle against free trade still a problem? How has it changed?

- How do you think people on the left can effectively confront the project of free trade today while at the same time challenging both far-right nationalism and neoliberal globalization?

The responses varied. Some, such as our first contributor, Marjorie Griffin Cohen, focused more on the day-to-day work of mobilizing the campaign. As co-chair of both the Coalition Against Free Trade in Toronto and the Pro-Canada Network, Cohen played a central role in galvanizing opposition to free trade, while at the same time serving on the Executive of the National Action Committee on the Status of Women (NAC). As such, Cohen documents the central role played by feminists in the early days of anti-free trade organizing. As the Canadian Labour Congress (CLC) was initially reluctant to address the issue, she notes that the NAC acted as a hub for anti-free trade organizing, bringing together feminists, labour activists, religious organizations, artists and other concerned groups. She explores how, through their research, NAC worked to frame free trade as not just a class issue but also a feminist issue. Moreover, she speaks to the ambiguities of nationalism in organizing on the ground, noting that most activists "were not isolationists or protectionists, or particularly nationalistic." As she notes, "they did not adhere to nationalism in the traditional sense of 'my country, right or wrong,' nor did they believe they were 
supporting a state structure that met their needs." In practice, activists were in "constant confrontation with the might of the state, and its corporate backers."

Others, such as Paul Kellogg focus more on the ideological debates that shaped free trade as an issue. Active in Ontario at the time, he notes the pervasiveness of nationalism in framing these struggles, whose echoes in Trump era 'America-first' rhetoric, speak to "the partial and incomplete nature of that era's anti-free trade politics." While the movement against free trade had potential, he argues that these politics led activists on the left to make a series of strategic missteps in addressing key issues of the day. Most notably, he argues that viewing the US as the enemy, and Canada as a comprador of American Empire, failed to acknowledge the complicity of Canada in transnational capitalism during this time, seeking to break down national tariff barriers in other economic jurisdictions. For Kellogg, this meant that left-nationalists were unable to view Canada as a capitalist state, subsequently misreading nationalism in Québec and Indigenous movements for self-determination. This helps to explain why the critique on the left was not as prominent during the most recent renegotiation of NAFTA - the veracity of left-nationalism analysis diminished as Canada's role in transnational capitalism intensified following the 1980s.

This critique is echoed by our third contributor, William Carroll. During the time that CUSFTA was being negotiated, Carroll was in British Columbia confronting the first neoliberal government in Canada, under Bennett's restraint program (Magnusson et al, 1984), while investigating the networks linking the capitalist class transnationally. In Corporate Power and Canadian Capitalism (1986), he had already noted that Canada's financial-industrial elite had maintained and consolidated their competitive position at the centre of a transnational intercorporate network. Along these lines, Carroll's article also critiques the left nationalism that underpinned much of the anti-free trade movement of the 1980s. Like Kellogg, Carroll notes that the persistence of nationalism in understanding free trade struggles speaks to the failure of the movement. "In placing national sovereignty at the centre of the narrative," he notes, "it veiled the class relations - the generative mechanisms - that actually drove 'free trade', and thereby failed to articulate the need for an alternative to capitalist class power." The challenge for the left, he argues, "is to reposition national-popular tropes, disentangling them from the hegemonic discourses of the capitalist state, setting them within an alternative whose trajectory is toward internationalism: the common interest we share in creating a world in which human thriving and ecological health are regnant values."

Claude Vallancourt, our fourth contributor, shifts focus to the early 2000s, describing his involvement with ATTAC - the Association pour la Taxation des Transactions financières et pour l'Action Citoyenne - and the altermondialiste networks emerging in Québec during this time. The question of nationalism had been different in Québec, where the Parti Québécois initially supported free trade as a strategy for economic independence. Responding to Premier René Lévesque's proposal of a "beau risque," Québec was a centre for Conservative votes in 1988, making up over one-third of the total seats won federally, posing a challenge for opponents of free trade in the province and across Canada. Vallaincourt speaks to how a powerful movement against free trade emerged in Québec through the 1990s that also challenged the pro-free trade position in the 
movement for sovereignty. He then goes onto appraise the current conjuncture. As the free trade regime became increasingly entrenched, he describes how the struggle has shifted from stopping the signing of free trade agreements, to mobilizing against the most harmful effects of already negotiated agreements, and he speaks to how the movement against free trade might move forward today.

\section{Conclusion and Directions for Future Research}

The articles help us to understand the political context today.

On the one hand, remembering the history of these struggles helps us to make sense of how conversative forces have taken the mantle of anti-free trade activism today. As Carroll notes, drawing from Fraser (1995), the enduring nationalist thread speaks to how resistance to free trade has been steeped in the affirmation of existing identities. While the invocation of nationalism has gained easy traction in building popular opposition given its familiarity, it also risks veiling the ways in which collective identities are complicit in the reproduction of power relationships both at home and abroad.

On the other hand, the struggle against free trade has also contributed to what Carroll describes as "transformative practices," pushing people out of their comfort zones, to explore new ways of imagining themselves and their relationship to the world around them, focusing on systemic change rather than the retrenchment of national boundaries. Indeed, over the course of three decades, there has been a tendency to move from affirmative to transformative strategies.

As our contributors note, the struggles against free trade have paved the way for emergent struggles confronting deepening inequality, ecological degradation, and the enduring colonial practices of the Canadian settler state. Indeed, the urgency of popular opposition to this economic regime has only become more pronounced in the face of the growing climate crisis. This has generated openings for a new progressive critique of free trade and economic globalization through the adoption of an ecological-activist lens.

Along these lines, there is much more work to be done in fostering our collective memories, revisiting past strategies and exploring the potential for progressive change. While each of the articles in this volume provides insights on the nature of free trade struggles, they do not tell the whole story. The Special Issue is largely orientated towards the early days, looking at the struggle, and the ensuing debates, that took place in the 1980s. With the exception of Vallancourt, the authors do not get into the shifting terrain of free trade activism in the 1990s and 2000s. Moreover, the focus of this volume has largely been on the Canadian context. However, activists were also building cross-border solidarity through this time. More research is needed in documenting the transnational networks forged by activists across borders, especially in the early years (see Ayres, 2004; Macdonald, 2002; Stillerman, 2003). Finally, the voices that are represented are largely academic and come from distinctive class, racialized and gendered locations. Going forward, there are many more voices that must be included to provide a fuller understanding of the dynamics of free trade. As Cohen notes, the Coalitions also included representatives from a variety of different 
backgrounds and perspectives, including the Assembly of First Nations, faith organizations and environmental groups.

Therefore much more work needs to be done in documenting the role of these communities and to foster more broadly the collective remembering of anti-free trade struggles and their relevance for politics today. This special issue is just the beginning of a broader project of remembering anti-free trade activism of the past, both to make sense of the current conjuncture of free trade politics and to inform progressive strategies against free trade for the future. Drawing inspiration from projects such as the WTO History Project, we plan to provide a fuller account of these struggles through contributing to the development of a public archive where these stories can be shared. To build on this project, we must include other voices that account for the diversity of participants who have fought against free trade, both past and present.

\section{Secondary Sources}

Aaronson, Susan A. 2001. Taking Trade to the Streets: The Lost History of Public Efforts to Shape Globalization. Ann Arbor: University of Michigan Press.

Ayres, Jeffrey. 1998. Defying conventional wisdom: Political movements and popular contention against North American free trade. Toronto: University of Toronto Press.

Ayres, Jeffrey M. 2003. “Contesting Neoliberalism: The Political Economy of Transnational Protest," in Marjorie Griffin Cohen and Stephen McBride, Global Turbulence: Social Activists' and State Responses to Globalization, Aldershot: Ashgate.

Ayres, Jeffrey. 2004. "Power Relations Under NAFTA: Reassessing the Efficacy of Contentious Transnationalism." Studies in Political Economy. 74: 101-123.

Bashevkin, Sylvia. 1989. "Free Trade Canadian Feminism: The Case of the National Action Committee on the Status of Women." Canadian Public Policy, 15(4): 363-375.

Brodie, Janine and Marjorie Griffin Cohen, eds., 2007. Remapping Gender in the New Global Order, London: Routledge.

Cohen, Marjorie Griffin and Stephen McBride, eds., 2003. Global Turbulence: Social Activists' and State Responses to Globalization, Aldershot: Ashgate.

Fraser, Nancy. 1995. 'From redistribution to recognition? Dilemmas of justice in a "post-socialist" age.' New Left Review 212:68-93. 
Hamelin, Spencer. 2017. "A New Scale of Activism: Canadian Unions and the North American Free Trade Agreement, 1992-1999." Labour/Le Travail, 80: 157-184.

Huyer, Sophia. 2004. "Challenging Relations: A Labour-NGO Coalition to Oppose the Canada-US and North American Free Trade Agreements, 1985-1993." Development in Practice. Vol. 14(1/2): 48-60.

Inwood, Gregory J. 2005. Continentalizing Canada: The Politics and Legacy of the Macdonald Royal Commission. Toronto: University of Toronto Press.

Kellogg, Paul. 2019. "Finding the Axis of Solidarity - Populist Protectionism and the End of NAFTA." Studies in Political Economy 100 (1): 65-81.

Kinsman, Gary. 2018. “AIDS Activism: Remembering Resistance versus Socially Organized Forgetting," In Suzanne Hindmarch, Michal Orsini and Marilou Gagnon (eds.), Seeing Red: HIV/AIDS and Public Policy in Canada. Toronto: University of Toronto Press, pp. 311333.

MacDonald, Laura. 2002. "Globalization and social movements: Comparing women's movements responses to NAFTA in Mexico, the USA and Canada." International Feminist Journal of Politics 4(2): 151-172.

McKay, Ian. 2005. Rebels, reds, radicals: Rethinking Canada's left history. Toronto: Between the Lines.

Stillerman, Joel. 2003. "Transnational activist networks and the emergence of labor internationalism in the NAFTA countries." Social Science History, 27(4): 577-601.

\section{Partial Bibliography, 1982-1995}

Bakker, Isa. 1989. "Now you see it, Now you don't: The Social Wage and the Free Trade Agreement," Canadian Dimension, 22(7): 8-9.

Bakker, Isa. 1988. “Women and Free trade: What's at Risk?,” Canadian Dimension, 21(8): 4-5.

Brodie, Janine. 1989. “The ‘Free Trade’ Election.” Studies in Political Economy. Spring 1989, 28. 
Campbell, Bruce. 2013. "FTA at 25, NAFTA at 30," Canadian Centre for Policy Alternatives, https://www.policyalternatives.ca/publications/commentary/fta-25-nafta-20

Cameron, Duncan, ed. 1986. The Free Trade Papers. Toronto: Lorimer.

Cameron, Duncan, ed. 1988. The Free Trade Deal. Toronto: Lorimer.

Cameron, Duncan, and Mel Watkins, eds. 1993. Canada Under Free Trade. Toronto: James Lorimer \& Company.

Canadian Labour Congress. 1986. “Free Trade: Our Canada or Theirs?” Canadian Labour, 31(7) (September).

Carroll, William. 1986. Corporate Power and Canadian Capitalism. Vancouver: University of British Columbia Press.

Carroll, William K. 1984. 'The Solidarity Coalition.’ Pp. 94-114 in Warren Magnusson, William K. Carroll, Charles Doyle, Monika Langer, and R.B.J. Walker (eds.), The New Reality. Vancouver: New Star Books.

Clarkson, Stephen, 1993. "Economics: The New Hemispheric Fundamentalism, in Grinspun, Ricardo and Maxwell A. Cameron, The Political Economy of North American Free Trade. Montreal and Kingston: McGill-Queen's University Press.

Cohen, Marjorie Griffin. 1987. Free Trade and the Future of Women's Work: Manufacturing and Service Industries, Toronto: Garamond Press.

Cohen, Marjorie Griffin, 1987. Free Trade in Services: An Issue of Concern to Women, Ottawa: Canadian Advisory Council on the Status of Women.

Cohen, Marjorie Griffin, 1991. "Unemployment and Regional Inequality: Economic Policy and Trade Theory," in Daniel Drache and Meric Gertler, The New Era of Global Competition: State Policy and Market Power. Montreal and Kingston: McGill-Queen's University Press.

Cohen, Marjorie Griffin, 1992. "The Lunacy of Free Trade," in Jim Sinclair, Jim, Crossing the Line: Canada and Free Trade with Mexico, Vancouver, New Star Books.

Drache, Daniel and Duncan Cameron. 1985. The Other Macdonald Report. Lorimer: Toronto. 
Drache, Daniel and Meric Gertler, eds. 1991. The New Era of Global Competition: State Policy and Market Power, Montreal and Kingston: McGill-Queen's University Press.

Department of External Affairs, Canadian Trade Policy for the 1980s: A Discussion Paper.

Finn, Ed and John Calvert. 1988. The Facts on Free Trade. Toronto: Lorimer.

Gandall, Marv. 1986. “Labour and Free Trade,” Canadian Dimension, 20(5): 9.

Gonick, Cy and Jim Silver. 1989. “The First Free Trade Budget," Canadian Dimension, 23(4): 1721.

Gonick, Cy and Jim Silver. 1989. "Fighting Free Trade,” Canadian Dimension, 23(3): 6-14.

Grinspun, Ricardo and Maxwell A. Cameron, 1993. The Political Economy of North American Free Trade, Montreal and Kingston, McGill-Queen's University Press.

Gudmundson, Fred. 1986. "Free Trade: The Real Agenda," Canadian Dimension, 20(5): 1-15.

Guilloud, Stephanie, ed. 2000. Voices from the WTO: An Anthology of Writings from the People who Shut Down the World Trade Organization: Stories and Photos from November 30December 3, 1999. Olympia WA: The Evergreen State College Bookstore distributor.

Kellogg, Paul. 1981. "Left Nationalists Move Right.” Preprint newspaper article, 6 June. Personal Archive.

Kellogg, Paul. 1986. “The Marxist Case against Left Nationalism.” Preprint newspaper article, 22 February. Personal Archive.

Kellogg, Paul. 1987. “J.B. McLachlan and the Free Trade Question.” Preprint newspaper article, 30 April. Personal Archive.

Kellogg, Paul. 1988a. "Free Trade and Nationalism.” Internal document, International Socialists, 15 February. Personal Archive.

Kellogg, Paul. 1988b. “Open Letter to Canadian Dimension.” Preprint newspaper article 10 September. Personal Archive. 
Kellogg, Paul. 1988c. “English-Canadian Nationalism: The Left's Greatest Weakness.” Preprint newspaper article, 25 November. Personal Archive.

Lapiere, Laurier, ed. 1987. If you Love this Country: Facts and Feelings on Free Trade.

Magnusson, W., William Carroll, Charles Doyle, Monika Langer and R.B.J. Walker (Eds.). 1984. The New Reality. Vancouver: New Star Books.

Moody, Kim, and Mary McGinn. 1992. Unions and Free Trade: Solidarity Vs. Competition. Detroit: Labor Notes.

Niosi, Jorge. 1985. Canadian Multinationals. Toronto: Garamond Press.

Panitch, Leo. 1989. “The Ambiguous Legacy of the Free Trade Election,” Canadian Dimension, 23(1): 18-19.

Panitch, Leo. 1987. 'Capitalist restructuring and labour strategies.' Studies in Political Economy 24: 131-49.

Resnick, Philip. 1982. “The Maturing of Canadian Capitalism.” Our Generation 15 (3): 11-25.

Roerick, Kyle. Much Ado About Free Trade?

Salutin, Rick and Terry Mosher. 1988. What's the Big Deal?

Sinclair, Jim, ed., 1992. Crossing the Line: Canada and Free Trade with Mexico, Vancouver: New Star Books.

Sinclair, Scott, 1993. "NAFTA and US Trade Policy: Implications for Canada and Mexico, in Grinspun, Ricardo and Maxwell A. Cameron. The Political Economy of North American Free Trade, Montreal and Kingston: McGill-Queen's University Press.

Swartz, Donald and Greg Albo. 1987. "Why the Campaign Against Free Trade Isn't Working," Canadian Dimension, 21(5): 23-27.

Warnock, John. 1988. Free Trade and the New Right Agenda. Vancouver: New Star Books. 
Watkins, Mel, 1993. "An Alternative Trade and Development Model for Canada," in Grinspun, Ricardo and Maxwell A. Cameron, The Political Economy of North American Free Trade, Montreal and Kingston: McGill-Queen's University Press.

Watkins, Mel. 1988. “The US-Canada free trade agreement.” Monthly Review 40(4): 34-43.

Whitaker, Reg. 1989. "No Laments For the Nation: Free Trade and the Election of 1988." The Canadian Forum, March.

Williams, Rick. 1989. "Election Post Mortem: Keeping the Free Trade Fight Alive," Canadian Dimension, 23(2): 31-33. 
A Partial Timeline - Free Trade Struggles and their context, 1982-1995

\begin{tabular}{|c|c|}
\hline \multicolumn{2}{|l|}{1982} \\
\hline & $\begin{array}{l}\text { Prime Minister Pierre Trudeau appoints the Royal Commission on the Economic } \\
\text { Union and Development Prospects for Canada (aka Macdonald Commission) } \\
\text { Patriation of the Canadian Constitution, without the support of Québec }\end{array}$ \\
\hline \multicolumn{2}{|l|}{1983} \\
\hline & $\begin{array}{l}\text { Department of External Affairs, Canadian Trade Policy for the 1980s: A Discussion } \\
\text { Paper }\end{array}$ \\
\hline \multicolumn{2}{|r|}{ ( } \\
\hline & $\begin{array}{l}\text { Federal elections; Brian Mulroney elected for the first time. } \\
\text { - In Québec, Premier Réné Levesque promotes "beau risque" (fine gamble), and } \\
\text { backs Mulroney over Turner } \\
\text { McDonald Commission presents its recommendations to Mulroney for a free trade } \\
\text { agreement with the United States }\end{array}$ \\
\hline & $\begin{array}{l}\text { Solidarity Coalition forms (BC) } \\
\text { - Located in British Columbia to combat the "restraint" program undertaken by } \\
\text { BC's Social Credit government - the first neoliberal project in Canada. }\end{array}$ \\
\hline Sept 4 & $\begin{array}{l}\text { Conservative Party led by Brian Mulroney wins a majority government } \\
\text { - Ran against free trade }\end{array}$ \\
\hline \multicolumn{2}{|l|}{1985} \\
\hline Mar 11 & $\begin{array}{l}\text { Council of Canadians founded } \\
\text { - by Mel Hurtig and a group of prominent Canadians including Maude Barlow, } \\
\text { Tommy Douglas, Margaret Atwood, Farley Mowat, David Suzuki and many } \\
\text { others, } \\
\text { - the Council's goals were: "a new and better Canada with more and better jobs } \\
\text { for Canadians, a higher standard of living for Canadians, and a sovereign } \\
\text { Canada that plays an important role among the world community of nations." }\end{array}$ \\
\hline Sept 4 & $\begin{array}{l}\text { Canadian Auto Workers Union founding convention, breaking away from United } \\
\text { Auto Workers in the United States. }\end{array}$ \\
\hline Sept 5 & $\begin{array}{l}\text { Macdonald Commission Report is released } \\
\text { - The Royal Commission on the Economic Union and Development Prospects for } \\
\text { Canada } \\
\text { - Four days after publication of the Macdonald Report, Mulroney declares } \\
\text { support of free trade the US. } \\
\text { The Other Macdonald Report: The Consensus on Canada's Future That the Macdonald } \\
\text { Commission Left Out is released. }\end{array}$ \\
\hline
\end{tabular}




\begin{tabular}{|c|c|}
\hline & $\begin{array}{l}\text { - A compilation of documents presented to the Commission by popular sector } \\
\text { groups that were left out of the Macdonald Report. Edited by Duncan } \\
\text { Cameron and Daniel Drache }\end{array}$ \\
\hline Dec & $\begin{array}{l}\text { Coalition Against Free Trade (CAFT) forms in Toronto } \\
\text { - First anti-free trade coalition } \\
\text { - Coalition grew from } 30 \text { to } 55 \text { groups, co-chaired by Marjorie Griffin Cohen } \\
\text { - Groups at the first meeting included UAW/CAW, the Toronto Labour Council, } \\
\text { Assembly of First Nations, National Farmers Union, United Church, NAC, } \\
\text { Writers Union, Playwrights Union, Social Planning Council, National Anti- } \\
\text { Poverty Organization, the Canadian Environmental Law Association, Federation } \\
\text { of Students and about } 20 \text { other groups (Cohen, 5) }\end{array}$ \\
\hline \multicolumn{2}{|l|}{1986} \\
\hline & Publication of The Free Trade Papers, edited by Duncan Cameron \\
\hline \multirow[t]{2}{*}{ January } & $\begin{array}{l}\text { Dialogue '86 Economic Roundtable in Ottawa brings together people from } \\
\text { government, labour, business and other groups. It was the first national airing of } \\
\text { criticism of free trade and the beginnings of cross-sectional alliances. }\end{array}$ \\
\hline & $\begin{array}{l}1986 \text { (to 1993): The Uruguay Round negotiations of the General Agreement on Tariffs } \\
\text { and Trade (GATT) begins } \\
\text { - This round led to the creation of the World Trade Organization (WTO) } \\
\text { - Broad mandate to extend rules to agriculture, textiles, intellectual property, } \\
\text { investment policy } \\
\text { - Involved } 123 \text { countries, including Canada }\end{array}$ \\
\hline March & $\begin{array}{l}\text { Anti-Free Trade Review, Massey Hall, Toronto. Cultural event with the Air Farce, } \\
\text { Sylvia Tyson, Eric Peterson and many other performers and activists opposed to free } \\
\text { trade. }\end{array}$ \\
\hline \multicolumn{2}{|l|}{1987} \\
\hline & $\begin{array}{l}\text { Publication of If You Love this Country: Facts and Feelings on Free Trade, edited by } \\
\text { Laurier } \\
\text { Publication of Free Trade and the Future of Women's Work: Manufacturing and } \\
\text { Service Industries by Marjorie Griffin Cohen }\end{array}$ \\
\hline March & $\begin{array}{l}\text { Pro-Canada Network (PCN) forms (initial meeting in Ottawa) } \\
\text { - Formed during "The Maple Leaf Summit" (held in unison with the "Shamrock } \\
\text { Summit" between Brian Mulroney and Ronald Reagan in Quebec City) to fight } \\
\text { against free trade } \\
\text { - Later renamed the Action Canada Network (ACN) in } 1991 \text { to encourage more } \\
\text { collaboration in Québec } \\
\text { - Initial co-chairs: Marjorie Cohen, Nancy Riche (vice-president of the CLC), Mel } \\
\text { Hurtig (honorary chair of the Council of Canadians), and Gerald Larose } \\
\text { (President of Confederation des syndicats nationaux (CSN)) }\end{array}$ \\
\hline
\end{tabular}




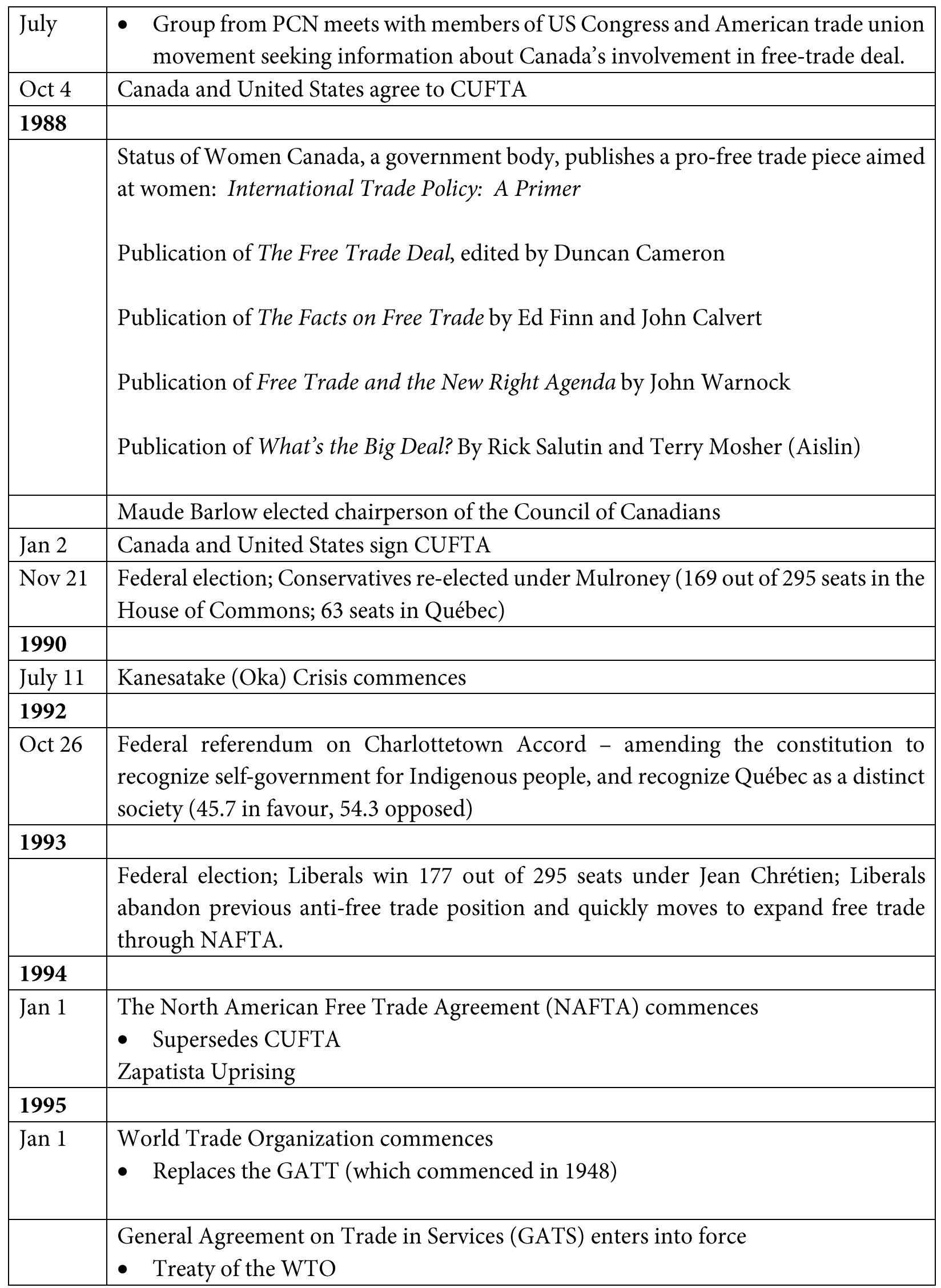




\begin{tabular}{|l|l|}
\hline & $\begin{array}{l}\text { Result of the Uruguay Round of negotiations } \\
\text { Treaty extended multilateral trading system to service sector }\end{array}$ \\
\hline $\begin{array}{l}\text { Multilateral Agreement on Investment (MAI) was drafted in secret between OECP } \\
\text { members } \\
\text { - Sought to establish a body of universal investment laws granting corporations } \\
\text { unconditional financial rights that would supersede national laws } \\
\text { Eventually died in Oct. } 1998 \text { due in part from pressure from civil society } \\
\text { organizations of OECP member countries that was initiated and led by Tony } \\
\text { Clarke, who had been chair of Action Canada Network and worked with the } \\
\text { Conference of Bishops, until he was fired for his anti-free trade activity. }\end{array}$ \\
\hline Oct 30 & Referendum on Sovereignty in Québec (49.5\% in favour, 50.5\% opposed) \\
\hline
\end{tabular}

\section{Contributors:}

William K. Carroll's research interests are in the political economy of corporate capitalism, social movements and social change, and critical social theory and method. A member of the Sociology Department at the University of Victoria since 1981, and founding Director of UVic's interdisciplinary program in Social Justice Studies, Dr. Carroll's books include Regime of Obstruction: How Corporate Power blocks Energy Democracy, Organizing the 1\%: How Corporate Power Works (with J.P. Sapinski), Expose, Oppose, Propose: Alternative Policy Groups and the Struggle for Global Justice, A World to Win (with Kanchan Sarker), The Making of a Transnational Capitalist Class, Corporate Power in a Globalizing World, Corporate Power and Canadian Capitalism, Remaking Media (with Bob Hackett), Critical Strategies for Social Research and Organizing Dissent. Carroll's involvement in the struggle against 'free trade' was part of his opposition to transnational neoliberalism, dating from 1983 to the present.

Marjorie Griffin Cohen is a feminist economist who is a professor emeritus of Political Science and Gender, Sexuality and Women's Studies at Simon Fraser University. She has written extensively in the areas of political economy and public policy with special emphasis on the Canadian economy, women, labour, electricity deregulation, energy, climate change and labour, and international trade agreements. She was very active in the anti-free trade movement and was co-chair of the Coalition Against Free Trade in Toronto, and co-chair of the national coalition The Pro-Canada Network. At the same time, she was on the Executive of the National Action Committee on the Status of Women and provided the initial analyses of the potential impact on women and on the services sector. Subsequently she has served on several boards and commissions in British Columbia and Saskatchewan, was the co-founder of the Canadian Centre for Policy Alternatives in BC and was its first Chair. More recently she was the first Chair of the B.C. Fair 
Wages Commission. Among her awards are the Galbraith Prize in Economics and Social Justice (2016) and the Charles Taylor prize for excellence in policy research (2020).

Paul Kellogg is a Professor in the Centre for Interdisciplinary Studies at Athabasca University in Edmonton Alberta. During the 1980's era controversy over CUFTA, he was a graduate student first at York University in Toronto, and then at Queen's University in Kingston. During the 1990's era controversy over NAFTA, he was helping to raise a couple of children in Toronto - first as a policy analyst working on public automobile insurance during the one-term NDP government in Ontario, and then as a lecturer in the School of Politics and Department of Public Administration at Ryerson University. During those years, he wrote extensively on free trade and globalization, in both the scholarly and popular press. During the early $21^{\text {st }}$ century controversies over globalization - including opposition to the (now-abandoned) FTAA - he was actively involved in many of the big mobilizations, including the May 2001 protests against the Summit of the Americas in Quebec City, the June 2002 protests against the G8 in Kananaskis Alberta and the January 2006 World Social Forum in Caracas, Venezuela. Those latter three experiences prompted him to help organize two grassroots coalitions - the Venezuela We are With You Coalition, and Toronto-Bolivia Solidarity.

Claude Vallancourt is president of ATTAC-Québec. He is an essayist and novelist, and member of the editorial collective of the magazine, $\dot{A}$ bâbord! Much of his writing focuses on culture, economics and criticism of the neoliberal system.

\section{Editors:}

Benjamin Christensen is a sociology faculty member in the Department of Humanities and Social Sciences at Douglas College in New Westminster, British Columbia. His research interests include corporate activism in Canada, Canadian pension policy, and Canadian political economy. You can find his research publications such as Studies in Political Economy, Canadian Journal of Political Science, and the CCPA's The Monitor.

Chris Hurl is assistant professor in the Department of Sociology and Anthropology at Concordia University in Montréal, Québec. His research, exploring urban governance, state formation, and the politics of the public sector in Canada, has appeared in Environment and Planning A, Studies in Political Economy, International Journal of Urban and Regional Research, Labour / Le Travail, and the Journal of Canadian Studies. He is the co-editor of Corporatizing Canada (Between the Lines, 2018). He first got involved in free trade activism with the APEC protests at the University of British Columbia in 1997. 